\title{
RESEARCH INTO THE FIRE PROPERTIES OF WOOD PRODUCTS MOST FREQUENTLY USED IN CONSTRUCTION
}

\author{
Romualdas MAČIULAITIS ${ }^{\mathrm{a}}$, Vladas PRANIAUSKAS ${ }^{\mathrm{b}}$, Grigory YAKOVLEV \\ ${ }^{a}$ Department of Building Materials, Vilnius Gediminas Technical University, Sauletekio al. 11, \\ LT-10223 Vilnius, Lithuania \\ ${ }^{b}$ Fire Research Centre of the Fire and Rescue Department under the Ministry of the Interior, Svitrigailos g. 18 , \\ LT-03223 Vilnius, Lithuania \\ ${ }^{c}$ Department of Building Materials, Kalashnikov Izhevsk State Technical University, Studencheskaia Str. 7, \\ Izhevsk 426069, Russia
}

Received 21 Aug. 2012; accepted 16 Apr. 2013

\begin{abstract}
Analysis of various wood products tested under the exposure to $30 \mathrm{~kW} / \mathrm{m}^{2}, 35 \mathrm{~kW} / \mathrm{m}^{2}, 40 \mathrm{~kW} / \mathrm{m}^{2}$, $45 \mathrm{~kW} / \mathrm{m}^{2}$ and $50 \mathrm{~kW} / \mathrm{m}^{2}$ heat flows in accordance with LST ISO $5657: 1999$ "Reaction to fire tests - ignitibility of building products using a radiant heat source" was performed. Selected boards were subjected to reaction to fire tests in accordance with LST EN 13823:2010 "Reaction to fire tests for building products". The tests were performed on $6 \mathrm{~mm}, 10 \mathrm{~mm}, 15 \mathrm{~mm}$ and $18 \mathrm{~mm}$ thick oriented strand boards (OSBs) and 24-mm thick wood particle boards (WPBs), both impregnated with BAK-1 fire retardant solution and non-impregnated. The average time to ignition (TTI) was determined. The impact of the impregnator on heat release rate, smoke formation and carbon dioxide $\left(\mathrm{CO}_{2}\right)$ emission in the course of combustion of impregnated and non-impregnated OSB and WPB was studied. In the course of the research, statistical analysis was performed and empirical equations and their correlation coefficients were obtained. Conclusions were formulated at the end of the study.
\end{abstract}

Keywords: time to ignition; wood products; fire properties; heat release rate; smoke production; $\mathrm{CO}_{2}$ emission.

Reference to this paper should be made as follows: Mačiulaitis, R.; Praniauskas, V.; Yakovlev, G. 2013. Research into the fire properties of wood products most frequently used in construction, Journal of Civil Engineering and Management 19(4): 573-582. http://dx.doi.org/10.3846/13923730.2013.810169

\section{Introduction}

In the modern global industry, wood has become very popular, thus its shortage is a growing problem. As many countries, including Lithuania, use wood in constructions, importance of this material must be taken into consideration. A wide choice of application options results in growing demand and requirements for the range of these products.

Fire safety is one of the main requirements set for buildings. Another important condition is to ensure that in case of fire, wood products would cause as low threat to civil population and fire-fighters as possible (Hakkarainen 2002; Frangi et al. 2009). This goal can be accomplished by using products, the fire properties of which limit the speed of fire propagation (Richardson, Batista 2001). When assessing products in terms of fire safety, it is also important to perform all the required tests exposing products to various heat flows and assess the heat release rate, decomposition (pyrolysis) of products and toxicity of substances emitted in the course of fire, including the amount of emitted smoke (Nyderis, Mačiulaitis 1999; White 2000; Bednarek et al. 2009; Šaučiuvenas, Griškevičius 2009).

Heat release rate, which is considered to be an important fire property, is highly significant for fire propagation. This statement is substantiated by the fact that fire temperature, which predetermines the propagation speed of fire itself depends on heat release rate and combustion time (Babrauskas, Peacock 1992; Władyka-Przybylak 1997; Mouritz et al. 2006; Filipczak et al. 2005).

Due to high temperatures, the combustion process is the main factor destroying materials and structures. This is the reason why even wooden structures should be made resistant to fire (Bednarek, Kaliszuk-Wietecka 2007; Chow, C. L., Chow, W. K. 2009).

Wooden structures are usually protected with the help of impregnation with fire retardant solutions; however, incorrectly selected impregnator may result in dramatic consequences in case of fire. Flammable

Corresponding author: Vladas Praniauskas

E-mail: vladas.praniauskas@vpgt.lt 
substances contained in impregnators may accelerate fire propagation even further (Bridžiuvienè, Lugauskas 2003; Półka 2008; Praniauskas, Mačiulaitis 2010; Pereyra, Giudice 2009). Instead of extinguishing a small seat of fire, the fire-fighting team would have to extinguish the whole building enveloped in flames. Most importantly, a building should not be constructed using a lot of flammable materials, but rather substances that could arrest and limit fire propagation (Babrauskas 2005; Wang et al. 2007; Chou et al. 2009). Fire-resistance enhancing materials used for the protection of wood and wood products act as a firewall arresting fire propagation, extending fire resistance and improving the durability of structures in general (Draizdeil 1998; Mačiulaitis, Praniauskas 2010).

It must also be noted that the combustion of large-molecular substances causes the emission of extensive amounts of carbon dioxide $\left(\mathrm{CO}_{2}\right) \cdot \mathrm{CO}_{2}$ is the final product of carbon oxidation. $\mathrm{CO}_{2}$ is a colourless gas with sour odour and flavour, approximately 1.5 times heavier than air. $\mathrm{CO}_{2}$ forces people to breathe more frequently, this way leading to a greater intake of toxic combustion products.

It causes vasodilatation as well as changes in blood $\mathrm{pH}$ and increased content of adrenaline in blood. Pursuant to the available data, it can be stated that in case of a short-term exposure to $\mathrm{CO}_{2}$ (15 minutes), the permissible concentration is $1.5 \%$ ( $\check{Z} u-$ kas et al. 2007).

The purpose of our study is to determine the impact of impregnated and non-impregnated (with fire retardant solution BAK-1) wood on fire propagation.

\section{Materials tested and test methodology}

The tests were performed with non-impregnated boards and boards impregnated with fire retardant solution BAK-1: $24 \mathrm{~mm}$ thick wood particle boards (WPB) and oriented strand boards (OSBs) of different thickness $(6 \mathrm{~mm}, 10 \mathrm{~mm}, 15 \mathrm{~mm}$ and $18 \mathrm{~mm})$. Five samples for both impregnated and non-impregnated wood products of each board type were prepared.

Fire hazard tests were carried out in accordance with the requirements of the standards LST ISO 5657:1999 (Fig. 1) and LST EN 13823:2010 (Fig. 2).

In accordance with the standard LST ISO 5657:1999, samples were cut out from test boards maintaining their real thickness $(150 \times 150 \mathrm{~mm})$. Then, a frame wrapped in aluminium foil was prepared. It was placed on one side of the sample while exposing only a circular opening to a heat flow (the heat flow is radiated by a spiral heated up to a certain temperature). Then, while exposing the sample to selected heat flows, the time to ignition (TTI) of the test boards was determined with the help of a stopwatch.

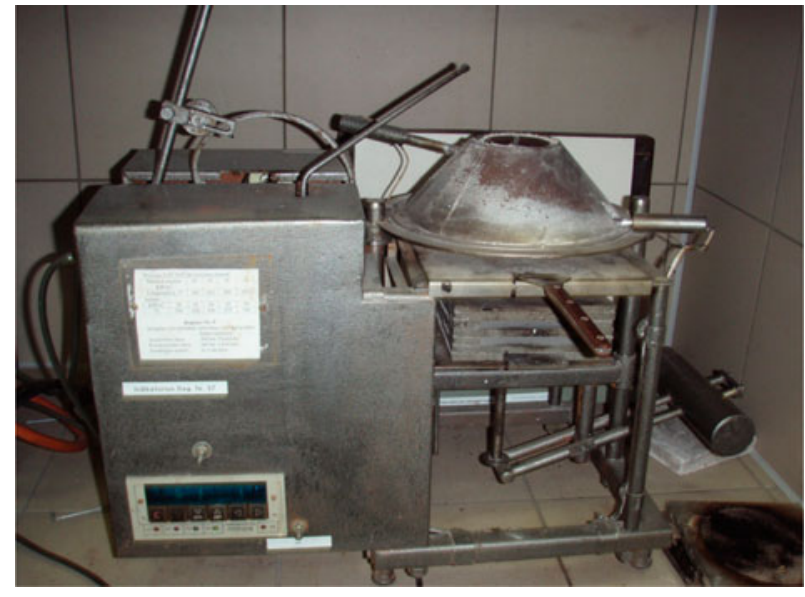

Fig. 1. LST ISO 565:1999 standard burning furnace

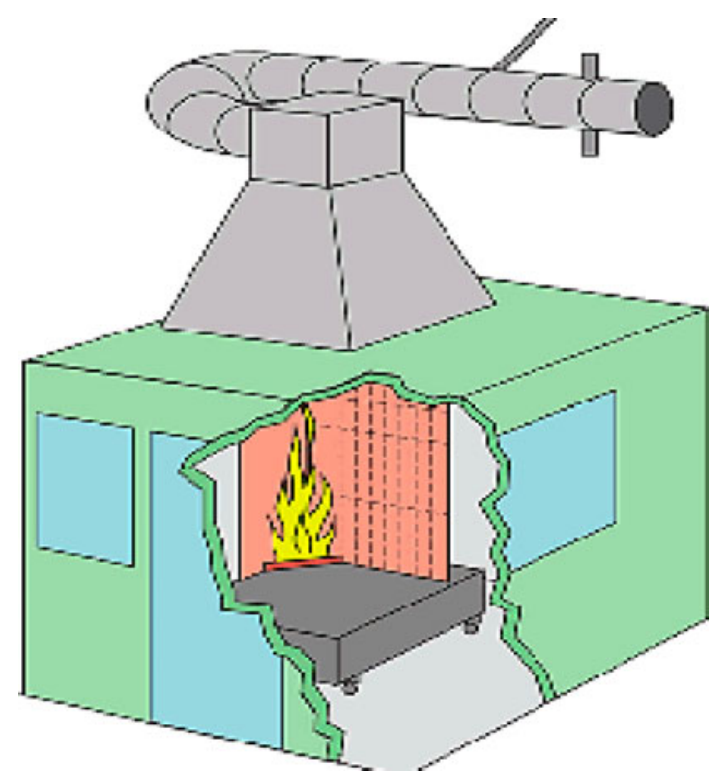

Fig. 2. LST EN 13823:2010 standard burning furnace

In accordance with the standard LST EN 13823:2010, the sample was made of two parts with dimensions $1500 \times 495 \mathrm{~mm}$ and $1500 \times 1000 \mathrm{~mm}$ (height $\times$ width) and exposed to the flame of the burner equipped at the bottom of the corner. Flame was obtained by combusting propane gas with a heat capacity of $(30.7 \pm 2.0) \mathrm{kW}$ supplied through a sandbox. The duration of the test was 25 minutes. However, during the first 5 minutes, an auxiliary burner was burned. It was equipped father from the sample, and the sample was not directly exposed to the flame. By means of the auxiliary burner, only the heat capacity and smoke formation of the burner were measured; therefore, the programme evaluated the heat capacity and smoke formation of the burner itself as well as provided only the test results of the sample once the sample was exposed to the flame of the main burner. The sample was exposed to the flame of the 
main burner for 20 minutes. The following operating parameters were obtained: heat formation, smoke formation, lateral flame spread and fall of flaming droplets and particles.

In order to summarise the test results, the average values of the obtained indicators were used.

\section{Test results and discussion}

First of all, non-impregnated products were tested in order to determine the ignition point. It was determined that at the heat flow of $10 \mathrm{~kW} / \mathrm{m}^{2}$ $\left(380{ }^{\circ} \mathrm{C}\right)$ and $20 \mathrm{~kW} / \mathrm{m}^{2}\left(500{ }^{\circ} \mathrm{C}\right)$ products did not ignite but charred. This might have happened because in order to initiate flame combustion, a certain concentration of volatile products (emission from the sample at the time of thermal decomposition when it is exposed to heat flows) and oxygen should be reached. However, in this case, under the exposure to smaller heat flows, a sufficient quantity of volatile products and concentration of the mix (of volatile products and oxygen) necessary for flame combustion was not reached. Therefore, only charring of the board and emission of volatile products without flame combustion proceeded. The test wood products that did not ignite after 900 seconds was terminated (see Table 1).

Ignition was obtained only at the heat flow of $30 \mathrm{~kW} / \mathrm{m}^{2}\left(590{ }^{\circ} \mathrm{C}\right)$. When gradually increasing the heat flow, the time to ignition decreased correspondingly as concentration of volatile products and oxygen necessary for flame combustion was reached faster.
However, it is possible to suggest that the ignition of neither WPB or OSB depends on the board thickness or the difference is minimal. The data presented in Table 1 prove that a thicker board may ignite faster than a thinner one. This may be influenced by additives used in board production and their concentration on the board surface because in case of a higher concentration of additives on the board surface, the concentration of volatile products and oxygen required for flame combustion may be reached faster or slower (White 2000; Richardson, Batista 2001; Morkevičius, Papreckis 2004).

Table 2 presents the results of combustibility tests of impregnated wood products and average times to ignition.

The results of the tests with impregnated products are presented starting from $35 \mathrm{~kW} / \mathrm{m} 2\left(620{ }^{\circ} \mathrm{C}\right)$ because the samples did not ignite when exposed to lower heat flows. Furthermore, the 24-mm thick WPB did not ignite even at $35 \mathrm{~kW} / \mathrm{m}^{2}\left(620^{\circ} \mathrm{C}\right)$. It can be explained by the fact that when boards are covered with BAK-1 fire retardant solution and exposed to heat flows, it absorbed salts intumesce, forming an additional protective layer (see Fig. 3) over the board surface exposed to the heat flow, which retains a part of the heat flow. As a result, the board surface is heated to a lesser degree and the amount of emitted volatile pyrolysis products is smaller.

Most frequently, differences were observed when exposing $6 \mathrm{~mm}$ OSB and WPB to $35 \mathrm{~kW} / \mathrm{m}^{2}\left(620{ }^{\circ} \mathrm{C}\right)$ heat flow. After impregnation with fire retardant solution BAK-1, the ignition time of OSB extended

Table 1. The average moisture content and the TTI of non-impregnated wood products exposed to heat flows of different capacities (temperature)

\begin{tabular}{lccccc}
\hline & \multicolumn{4}{c}{ Average values of the TTI (s) } \\
\cline { 2 - 6 } Indicators & OSB $(6 \mathrm{~mm})$ & OSB $(10 \mathrm{~mm})$ & OSB $(15 \mathrm{~mm})$ & OSB $(18 \mathrm{~mm})$ & WPB $(24 \mathrm{~mm})$ \\
\hline Moisture content, $(\%)$ & 8 & 6 & 8 & 8 & 6 \\
$30 \mathrm{~kW} / \mathrm{m}^{2}\left(590{ }^{\circ} \mathrm{C}\right)$ & 93.11 & 74.54 & 87.34 & 93.98 & 71.18 \\
$35 \mathrm{~kW} / \mathrm{m}^{2}\left(620^{\circ} \mathrm{C}\right)$ & 65.34 & 67.01 & 69.14 & 19.81 & 68.11 \\
$40 \mathrm{~kW} / \mathrm{m}^{2}\left(650{ }^{\circ} \mathrm{C}\right)$ & 26.45 & 28.34 & 24.11 & 18.7 & 32.11 \\
$45 \mathrm{~kW} / \mathrm{m}^{2}\left(675{ }^{\circ} \mathrm{C}\right)$ & 24.43 & 21.58 & 22.11 & 15.55 & 19.11 \\
$50 \mathrm{~kW} / \mathrm{m}^{2}\left(700{ }^{\circ} \mathrm{C}\right)$ & 19.15 & 17.64 & 16.48 & 15.01 \\
\hline
\end{tabular}

Table 2. The average moisture content and the TTI of impregnated wood products exposed to heat flows of different capacities (temperature)

Average values of the indicators of samples (s)

\begin{tabular}{lccccc}
\cline { 2 - 6 } Indicators & OSB $(6 \mathrm{~mm})$ & OSB $(10 \mathrm{~mm})$ & OSB $(15 \mathrm{~mm})$ & OSB $(18 \mathrm{~mm})$ & WPB $(24 \mathrm{~mm})$ \\
\hline Moisture content $(\%)$ & 8 & 8 & 6 & 8 & 8 \\
$35 \mathrm{~kW} / \mathrm{m}^{2}\left(620^{\circ} \mathrm{C}\right)$ & 78.52 & 75.8 & 74.65 & 27.11 & - \\
$40 \mathrm{~kW} / \mathrm{m}^{2}\left(650^{\circ} \mathrm{C}\right)$ & 29.63 & 28.2 & 23.11 & 24.11 & 41.19 \\
$45 \mathrm{~kW} / \mathrm{m}^{2}\left(675^{\circ} \mathrm{C}\right)$ & 27.52 & 22.27 & 17.89 & 16.87 & 22.20 \\
$50 \mathrm{~kW} / \mathrm{m}^{2}\left(700^{\circ} \mathrm{C}\right)$ & 18.39 & 18.81 & 13.91 \\
\hline
\end{tabular}




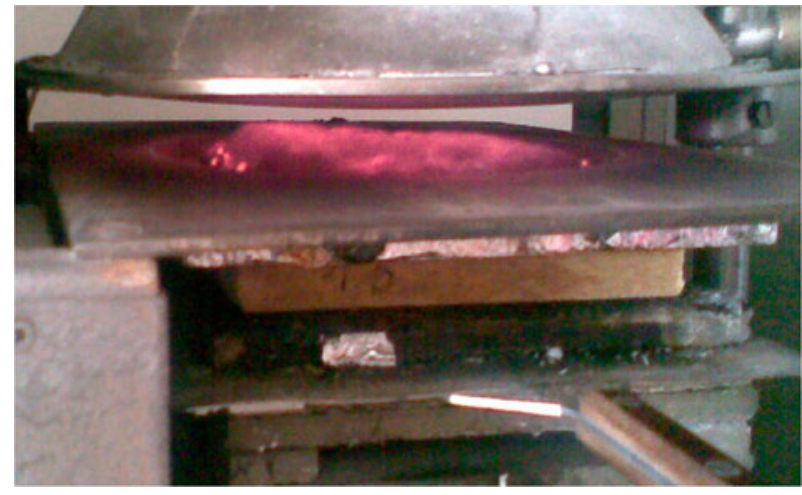

Fig. 3. Image of the intumescent protective layer which is formed during the test

by approximately 13 seconds, while WPB withstood the test and did not ignite.

When increasing the temperature, fire retardant provides worse protection against the impact of fire: the time differs from that of non-impregnated samples increasingly less and that difference amounts to $2-3$ seconds on average. Therefore, it can be presumed that the impact of fire retardant is not as effective

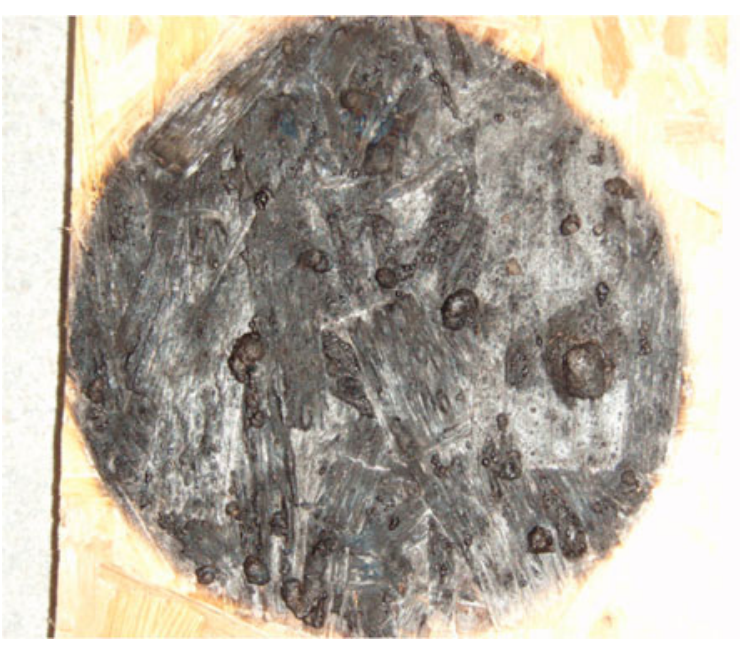

Fig. 4. Flame retardant residues on OSB when increasing the temperature. When the heat flow of $50 \mathrm{~kW} / \mathrm{m}^{2}\left(700{ }^{\circ} \mathrm{C}\right)$ is reached, the results of impregnated products were similar to those of nonimpregnated products; therefore, fire retardant becomes less effective at high temperatures. This might be explained by the fact that when exposed to high heat flows, the additional protective layer forming of the absorbed salts of the fire retardant arrests the heat flow; however, the heat flow that reaches the board surface is still sufficient for a concentration of the mix of pyrolysis gases and oxygen required for flame combustion.

On the other hand, OSB absorbs fire retardant solution differently, and one place of the board absorbs more salts, while another absorbs less. It can be observed after the test from the quantity of additional intumesced coating (Fig. 4).

The best result was achieved with WPB, which did not ignite at the heat flow of $35 \mathrm{~kW} / \mathrm{m}^{2}\left(620{ }^{\circ} \mathrm{C}\right)$ for as many as 23 minutes and more. The sample charred, although there was no flame, and it continued to smoulder. However, under the heat flow above $40 \mathrm{~kW} / \mathrm{m}^{2}\left(650{ }^{\circ} \mathrm{C}\right)$, fire retardant almost failed to protect WPB.

WPBs, $24 \mathrm{~mm}$ thick, and OSBs, $6 \mathrm{~mm}$, were selected for further tests in accordance with the standard LST EN 13823:2010.

As may be seen from Figure 5, as soon as WPB was exposed to the flame of the main burner, the heat release rate immediately began to increase and the maximum heat release rate $\left(H R R_{\max }\right)$ was reached after approximately 160 seconds. The heat release rate is the most important fire property, which influences fire propagation speed and its physical and chemical properties (Mouritz et al. 2006). The change time of the $\mathrm{HRR}_{\max }$ value has a particular importance: the shorter it is, the greater is the hazard for humans because if high temperatures are reached quickly, fire propagates faster blocking evacuation ways. When $\mathrm{HRR}_{\text {max }}$ is reached, heat release decreases as a result of the carbon layer, which inhibits the emission of flammable gases (Praniauskas et al. 2010). The decrease occurs gradually, and no heat surges as a

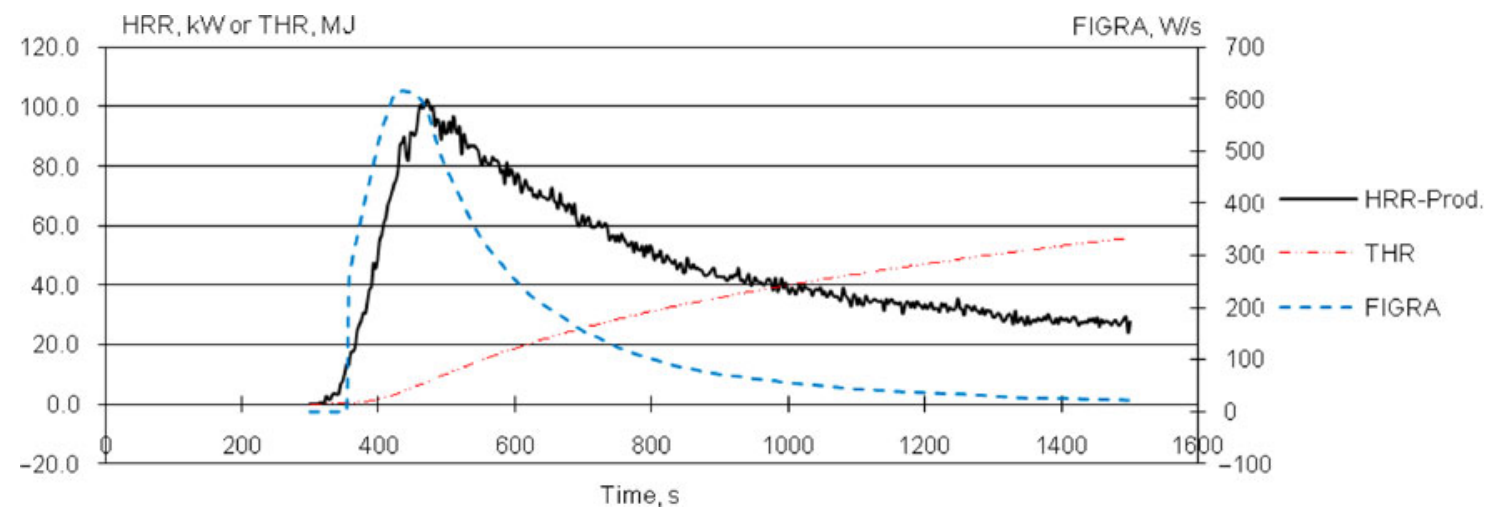

Fig. 5. HRR of non-impregnated $24 \mathrm{~mm}$ WPB 


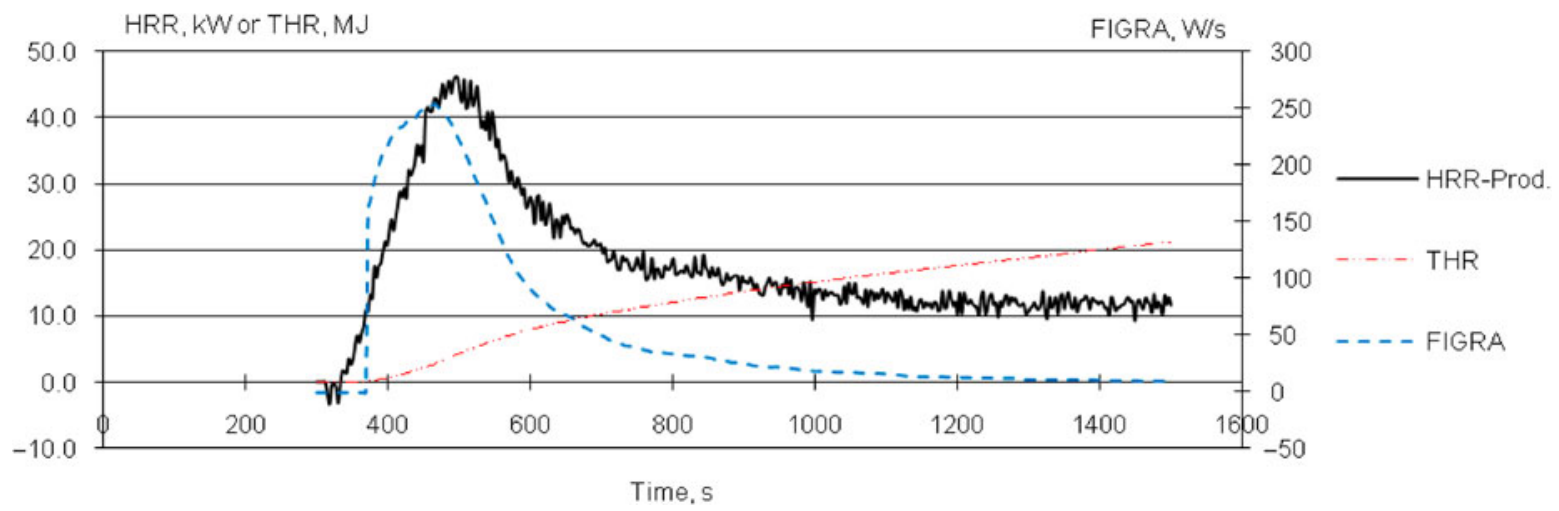

Fig. 6. HRR of impregnated $24 \mathrm{~mm}$ WPB. It was noticed that the amount of smoke released from a 24-mm thick WPB is nearly three times greater than that released from a non-impregnated board. It can be explained by the interaction between the fire retardant and a board as well as partial pyrolysis (Table 3)

result of the formation of cracks in the carbon layer are observed. The test was terminated in approximately 1500 seconds. According to FIGRA 0.2 MJ (the maximum relation between heat release rate and duration) equals to 615.7 [W/s], and the flammability class established according to LST EN 13501$1: 2007+\mathrm{A} 1: 2010$ standard is $\mathrm{D}(>250[\mathrm{~W} / \mathrm{s}]$ and $\leq 750[\mathrm{~W} / \mathrm{s}])$.

Figure 6 presents the curve of the test of reaction of 2-mm-thick WPB impregnated with BAK-1 fire retardant solution to fire. The highest value of the relation of the heat release rate and duration FIGRA = $249.6 \mathrm{~W} / \mathrm{s}$. All the heat released from the sample during $600 \mathrm{~s}$ from the beginning of the exposure to the flame of the main burner $\mathrm{THR}_{600}=13.7 \mathrm{MJ}$. The total amount of heat released $\mathrm{THR}=22$ MJ. Within 10 minutes from the beginning of the exposure of the sample to the main burner, approximately $62 \%$ of the total heat emission was released, and approximately $38 \%$ of the total heat emission was released during the remaining 10 minutes. The $\mathrm{HRR}_{\max }$ (HRR-Prod.) during the test was reached in approximately 4 minutes, after the sample was exposed to the flame of the main burner. In this case, the curves of HRR and FIGRA are very similar to those of WPB; however, they differ by values of these parameters. After WPB was impregnated with the fire retardant BAK-1 solution, the values of its parameters decreased as a result of the additional fire retardant protection.

According to the results obtained during the test, the WPB impregnated with BAK-1 fire retardant solution according LST EN 13501-1:2007 + A1:2010 is $120 \mathrm{~W} / \mathrm{s}$ and $\leq 250 \mathrm{~W} / \mathrm{s}$ and classified in C flammability class.

It was noticed that the amount of smoke released from a 24-mm-thick WPB is nearly three times greater than that released from a non-impregnated board. It can be explained by the interaction between the fire retardant and a board as well as partial pyrolysis (Table 3).
Table 3. Smoke release values of impregnated and nonimpregnated WPB

\begin{tabular}{lcc}
\hline $\begin{array}{l}\text { Smokiness } \\
\text { parameter }\end{array}$ & $\begin{array}{c}\text { Non-impregnated } \\
\text { WPB }(24 \mathrm{~mm})\end{array}$ & $\begin{array}{c}\text { Impregnated WPB } \\
(24 \mathrm{~mm})\end{array}$ \\
\hline SMOGRA & 7.8 & 19.5 \\
TSP $_{600}$ & 43.6 & 96.9 \\
TSP & 165 & 180 \\
\hline
\end{tabular}

SMOGRA - smoke growth rate. The maximum value of the relationship between the rate and duration of smoke formation from the sample) $\left[\mathrm{cm}^{2} / \mathrm{s}^{2}\right]$;

$\mathrm{TSP}_{600}$ - the total quantity of smoke forming from the sample within $600 \mathrm{~s}(300 \mathrm{~s} \leq \mathrm{t} \leq 900 \mathrm{~s})$ from the beginning of exposure of the flame of the main burner $\left[\mathrm{m}^{2}\right]$;

TSP - the total quantity of smoke forming from the sample $\left[\mathrm{m}^{2}\right]$;

FIGRA - fire growth rate. The maximum relationship between HRR and duration [W/s].

The test with a non-impregnated OSB was terminated because of rapid ignition. Sharp increase in the heat release rate is demonstrated in Figure 7. The test reached the maximum values and was terminated in approximately 200 seconds from the start of exposure of the sample to the main burner. The image of the sample at the time of the test and later is presented in Figure 8. Figure 7 shows that at the time of the termination of the test as FIGRA0.2 $\mathrm{MJ}[\mathrm{W} / \mathrm{s}] \sim 3000$.

A 6-mm-thick OSB impregnated with BAK-1 fire retardant solution showed better results (Fig. 9) than a similar non-impregnated board (Fig. 7), with the test of the latter having been terminated because of high parameters that exceeded all criteria. The maximum relationship between the heat release rate and the duration $F I G R A=555.5 \mathrm{~W} / \mathrm{s}$. The total amount of heat released from the sample within $600 \mathrm{~s}$ from the beginning of exposure to the flame of the main burner $T H R_{600}=20.8 \mathrm{MJ}$. The total amount of heat released $T H R=22$ MJ. Approximately $94 \%$ of the total heat was released within 10 minutes from the beginning of exposure of the flame of the main burner and around $6 \%$ was released within the remaining 10 minutes. This 


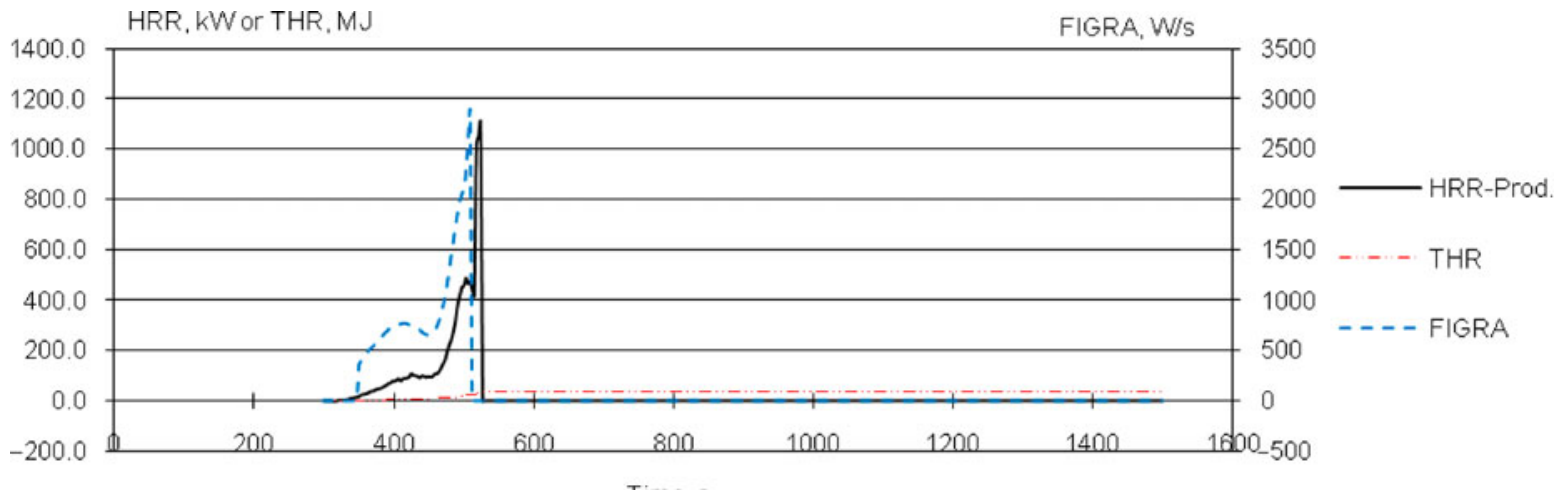

Fig. 7. HRR of non-impregnated $6 \mathrm{~mm}$ OSB

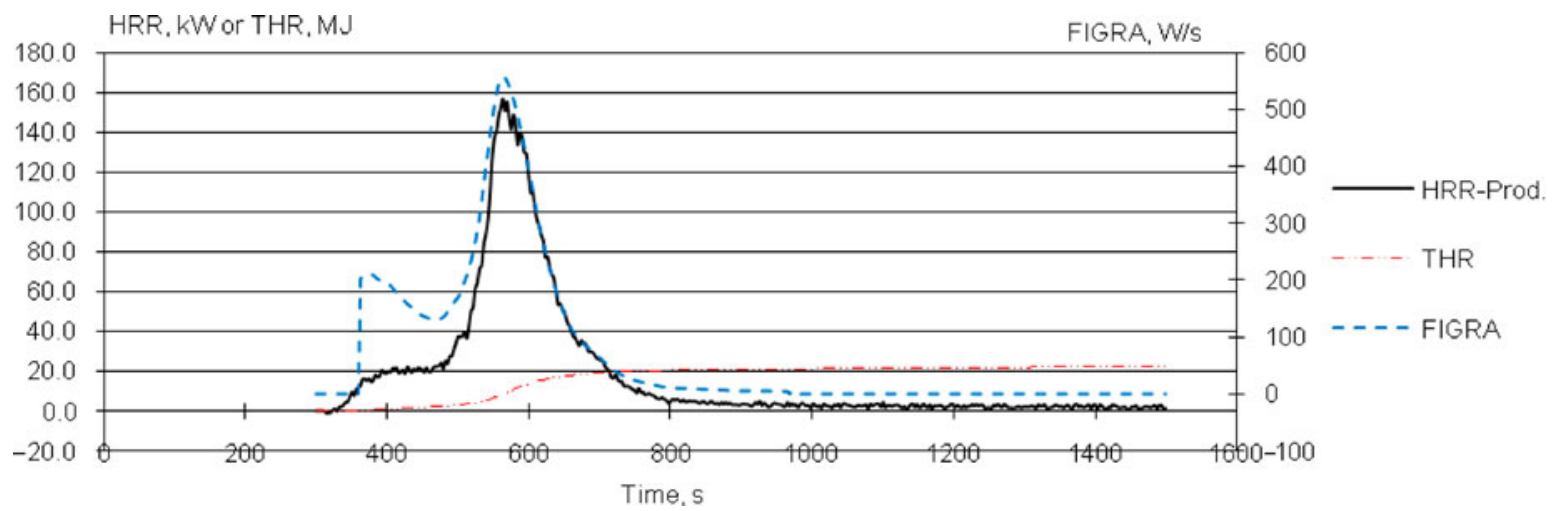

Fig. 8. Image of non-impregnated 6-mm-thick OSB during the test (a) and after terminating the test (b)

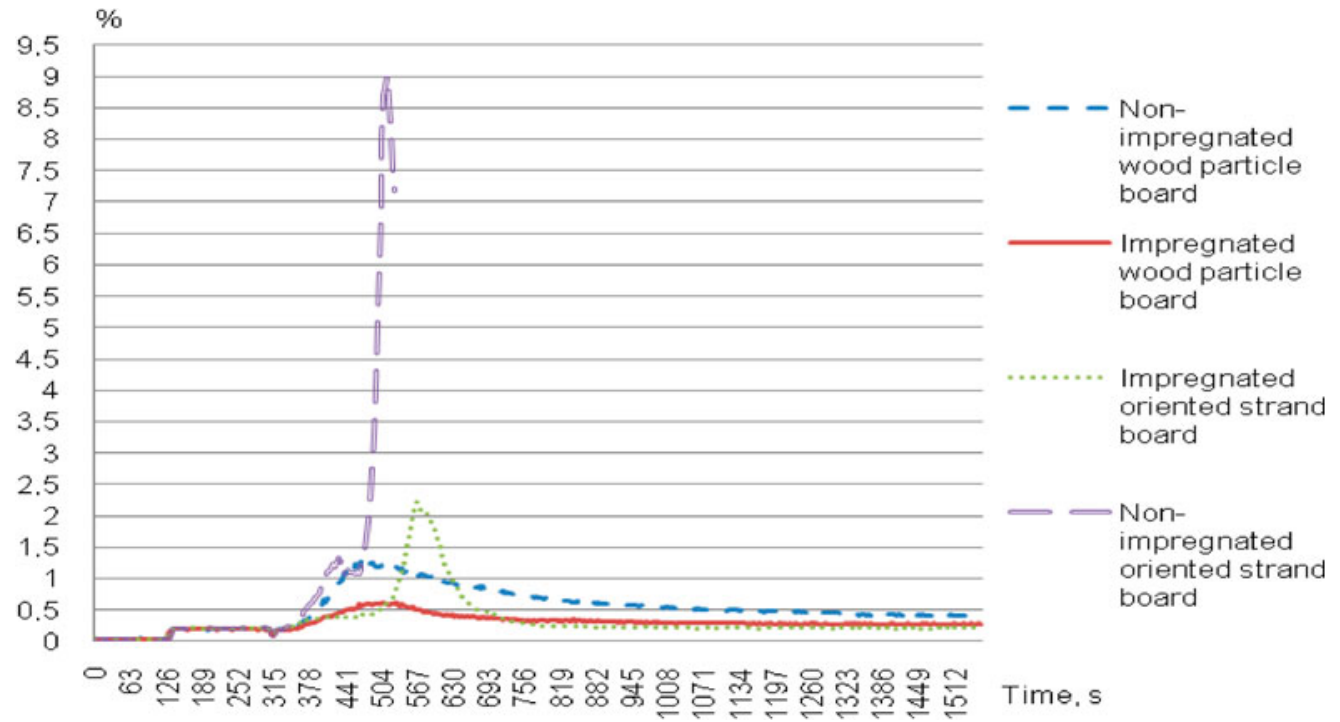

Fig. 9. HRR of impregnated $6 \mathrm{~mm}$ OSB

might have happened because after the first 10 minutes, the sample became burned through at the place where it was exposed to the flame and was no longer exposed to the flame. The $\mathrm{HRR}_{\max }$ (HRRProd.) during the test was reached in approximately 5 minutes after the sample was exposed to the flame of the main burner (Fig. 9). According to the results obtained during the test, the OSB impregnated with BAK-1 fire retardant solution is classified in D flammability class.

Even after terminating the test on the basis of the values of SMOGRA, it can be concluded that smoke release rate decreased after impregnating the OSB with fire retardant solution. Therefore, the impact of 
Table 4. Smoke release values of impregnated and nonimpregnated (before terminating the test) OSBs.

\begin{tabular}{lcc}
\hline $\begin{array}{l}\text { Smokiness } \\
\text { parameter }\end{array}$ & $\begin{array}{c}\text { Non-impregnated } \\
\text { OSB }(6 \mathrm{~mm})\end{array}$ & $\begin{array}{c}\text { Impregnated OSB } \\
(6 \mathrm{~mm})\end{array}$ \\
\hline SMOGRA & 82 & 36.1 \\
TSP $_{600}$ & - & 176.5 \\
TSP & - & 220 \\
\hline
\end{tabular}
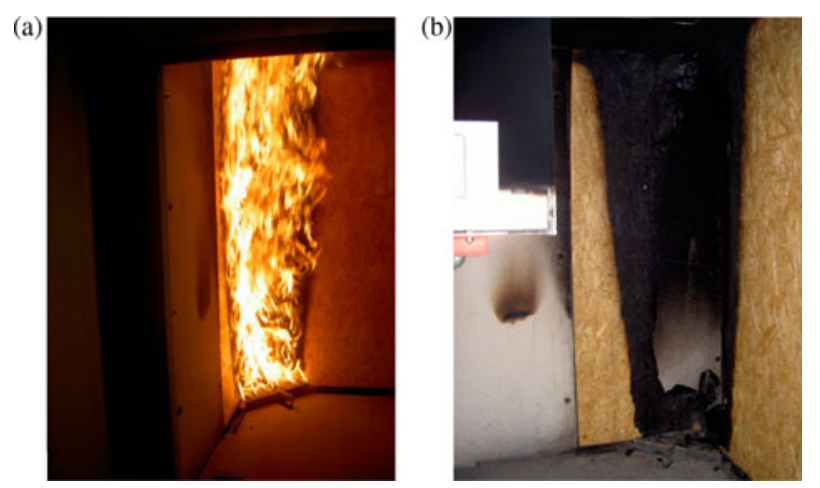

Fig. 10. $\mathrm{CO}_{2}$ release test results of impregnated (BAK-1) and non-impregnated 6-mm-thick OSB and 24-mm-thick WPB

the fire retardant is absolutely positive in this case (Table 4).

Analysis of the emission of $\mathrm{CO}_{2}$ determined during the tests shows that the amount of $\mathrm{CO}_{2}$ emitted from wooden boards impregnated with BAK-1 fire retardant solution was lower than that from nonimpregnated ones. $\mathrm{CO}_{2}$ emission from non-impregnated OSB and WPB started to increase rapidly almost from the beginning of the test, as soon as the sample was exposed to the flame of the main burner. In the case of non-impregnated WPB, a $\mathrm{CO}_{2}$ concentration limit of almost $1.3 \%$ was reached, while in the case of OSB, the hazardous $\mathrm{CO}_{2}$ concentration limit of $1.5 \%$ was exceeded (Žukas et al. 2007) (Fig. 10). Impregnated OSB reached a $\mathrm{CO}_{2}$ concentration limit of approximately $2.2 \%$, and in the case of nonimpregnated $\mathrm{OSB}$, the $\mathrm{CO}^{2}$ concentration limit was as high as $9 \%$ (Fig. 10). Therefore, fire retardant solution not only worsens the combustion properties of wood but also decreases the amount of $\mathrm{CO}_{2}$ emission. As a result, there is a greater possibility to save lives as well as wealth.

The results of the tests performed in accordance with the standard LST ISO 5657:1999 were processed statistically in order to derive equations for forecasting the time to ignition. Three parameters were selected to derive the equations: TTI (time $[\mathrm{S}]$ ), board thickness (thickness $[\mathrm{mm}]$ ) and heat flow (Q $[\mathrm{kW} / \mathrm{m} 2])$ to which the sample was exposed.

On the basis of regression analysis, it was established that the results obtained from the tests of non-impregnated and impregnated $\operatorname{OSB}(6,10,15$ and $18 \mathrm{~mm}$ thick) and WPB (24 mm thick) were the most suitable to forecast the time to ignition. Since the correlation coefficients $R$ of the first $(R=0.97826)$ and second $(R=0.98049)$ equation for non-impregnated boards were close to one, and the correlation coefficients $R$ of the third $(R=0.99216)$ and fourth $(R=0.99415)$ equation for impregnated boards were also close to one, it can be concluded that the selected equation model with a turning point is correct, and there is a high interdependence between the parameters (Rudskienè, Kulvietienè 1995; Borovikov 1998; Kleinbaum et al. 1998).

Therefore, the following empirical equations can be used for the forecasting of time to ignition of nonimpregnated (1) and (2) and impregnated (3) and (4) OSB and WPB:

$$
\begin{gathered}
\mathrm{y}_{1}=\left(52.128-0.683 \mathrm{x}_{1}\right) *\left(\mathrm{y}_{1} \leq 45.276\right)+ \\
\left(201.774-3.818 \mathrm{x}_{1}\right) *\left(\mathrm{y}_{1}>45.276\right) \\
y_{2}=\left(60.725-0.762 \mathrm{x}_{1}-0.434 \mathrm{x}_{2}\right) *\left(y_{2} \leq 45.276\right)+ \\
\left(196.62-3.818 \mathrm{x}_{1}-0.421 \mathrm{x}_{2}\right) *\left(y_{2}>45.276\right) \\
y_{3}=\left(74.334-1.137 \mathrm{x}_{1}\right) *\left(y_{3} \leq 34.74\right)+ \\
\left(299.813-6.416 \mathrm{x}_{1}\right) *\left(\mathrm{y}_{3}>34.74\right) \\
y_{4}=\left(75.430-1.106 \mathrm{x}_{1}-0.177 \mathrm{x}_{2}\right) *\left(y_{4} \leq 34.74\right)+ \\
\left(265.634-5.268 \mathrm{x}_{1}-0.488 \mathrm{x}_{2}\right) *\left(y_{4}>34.739\right)
\end{gathered}
$$

where: $y_{1,2,3,4}$ - time to ignition [s]; $x_{1}$ - power of the superficial heat flow to which the sample was exposed $\left[\mathrm{kW} / \mathrm{m}^{2}\right] ; x_{2}-$ thickness of OSB or WPB [mm]; $*\left(y_{1,2} \leq 45.27589\right)$ means that the equation is applicable when time to ignition $\leq 45.27589$ [s]. As demonstrated in Table 1, this equation is applicable when samples are exposed to heat flow power $>40 \quad\left[\mathrm{~kW} / \mathrm{m}^{2}\right]$; $*\left(y_{1,2}>45.27589\right)$ means that the equation is applicable when time to ignition $>45.27589$ [s]. As suggested in Table 1, this equation is applicable when samples are exposed to heat flow power $\leq 40 \quad\left[\mathrm{~kW} / \mathrm{m}^{2}\right]$; $*\left(y_{3,4} \leq 34.73916\right)$ means that the equation is applicable when time to ignition $\leq 34.73916$ [s]. As demonstrated in Table 1, this equation is applicable when samples are exposed to heat flow power $>40\left[\mathrm{~kW} / \mathrm{m}^{2}\right]$, and the equation is applicable to WPB when samples are exposed to heat flow power $>45\left[\mathrm{~kW} / \mathrm{m}^{2}\right]$; $*\left(y_{3,4}>34.73916\right)$ - means that the equation is applicable when time to ignition $>34.73916$ [s]. As suggested in Table 1, this equation is applicable when samples are exposed to heat flow power $\leq 40\left[\mathrm{~kW} / \mathrm{m}^{2}\right]$, and the equation is applicable to WPB when samples are exposed to heat flow power $\leq 45\left[\mathrm{~kW} / \mathrm{m}^{2}\right]$.

Tables 5 and 6 present the forecasted TTI values calculated in accordance with the Eqns (1)-(4) as well as the actual average TTI values for impregnated and non-impregnated OSB and WPB. As the obtained 
Table 5. Actual and forecasted values of TTI for non-impregnated OSB and WPB

\begin{tabular}{|c|c|c|c|c|c|c|c|c|c|c|c|}
\hline \multicolumn{12}{|c|}{ Non-impregnated OSB and WPB } \\
\hline \multirow[b]{2}{*}{$\begin{array}{l}Q, \\
\mathrm{~kW} / \\
\mathrm{m}^{2}\end{array}$} & \multicolumn{5}{|c|}{ Actual $T T I$ value (s) } & \multirow{2}{*}{$\begin{array}{l}T T I \text { according to } \\
\text { the Eqn }(1),(\mathrm{s}) \\
\text { OSB }(6 \mathrm{~mm}) ; \\
\text { OSB }(10 \mathrm{~mm}) ; \\
\text { OSB }(15 \mathrm{~mm}) ; \\
\text { OSB }(18 \mathrm{~mm}) ; \\
\text { WPB }(24 \mathrm{~mm})\end{array}$} & \multicolumn{5}{|c|}{ TTI according to the Eqn (2), (s) } \\
\hline & $\begin{array}{c}\text { OSB } \\
(6 \mathrm{~mm})\end{array}$ & $\begin{array}{c}\text { OSB } \\
(10 \mathrm{~mm})\end{array}$ & $\begin{array}{c}\text { OSB } \\
(15 \mathrm{~mm})\end{array}$ & $\begin{array}{c}\text { OSB } \\
(18 \mathrm{~mm})\end{array}$ & $\begin{array}{c}\text { WPB } \\
(24 \mathrm{~mm})\end{array}$ & & $\begin{array}{c}\text { OSB } \\
(6 \mathrm{~mm})\end{array}$ & $\begin{array}{c}\text { OSB } \\
(10 \mathrm{~mm})\end{array}$ & $\begin{array}{c}\text { OSB } \\
(15 \mathrm{~mm})\end{array}$ & $\begin{array}{c}\text { OSB } \\
(18 \mathrm{~mm})\end{array}$ & $\begin{array}{c}\text { WPB } \\
(24 \mathrm{~mm})\end{array}$ \\
\hline 30 & 93.1 & 74.5 & 87.3 & 94.0 & 87.5 & 87.23 & 79.55 & 77.87 & 75.77 & 74.5 & 71.98 \\
\hline 35 & 65.3 & 67.0 & 69.1 & 71.2 & 68.1 & 68.14 & 60.46 & 58.78 & 56.68 & 55.41 & 52.89 \\
\hline 40 & 26.5 & 28.3 & 24.1 & 19.8 & 32.1 & 24.81 & 27.64 & 25.91 & 23.74 & 22.43 & 19.83 \\
\hline 45 & 24.4 & 21.6 & 22.1 & 18.7 & 19.1 & 21.39 & 23.83 & 22.1 & 19.93 & 18.62 & 16.02 \\
\hline 50 & 19.2 & 17.6 & 16.5 & 15.6 & 15.0 & 17.98 & 20.02 & 18.29 & 16.12 & 14.81 & 12.21 \\
\hline
\end{tabular}

Table 6. Actual and forecasted values of TTI for impregnated OSB and WPB

\begin{tabular}{|c|c|c|c|c|c|c|c|c|c|c|c|}
\hline \multicolumn{12}{|c|}{ Impregnated OSB and WPB } \\
\hline \multirow[b]{2}{*}{$\begin{array}{l}Q, \\
\mathrm{~kW} / \\
\mathrm{m}^{2}\end{array}$} & \multicolumn{5}{|c|}{ Actual TTI value (s) } & $\begin{array}{l}\text { TTI according to } \\
\text { the Eqn (3), (s) }\end{array}$ & \multicolumn{5}{|c|}{ TTI according to the Eqn (4), (s) } \\
\hline & $\begin{array}{c}\text { OSB } \\
(6 \mathrm{~mm})\end{array}$ & $\begin{array}{c}\text { OSB } \\
10 \mathrm{~mm}\end{array}$ & $\begin{array}{c}\text { OSB } \\
(15 \mathrm{~mm})\end{array}$ & $\begin{array}{c}\text { OSB } \\
(18 \mathrm{~mm})\end{array}$ & $\begin{array}{c}\text { WPB } \\
(24 \mathrm{~mm})\end{array}$ & $\begin{array}{l}\text { OSB }(6 \mathrm{~mm}) \\
\text { OSB }(10 \mathrm{~mm}) ; \\
\text { OSB }(15 \mathrm{~mm}) ; \\
\text { OSB }(18 \mathrm{~mm}) ; \\
\text { WPB }(24 \mathrm{~mm})\end{array}$ & $\begin{array}{c}\text { OSB } \\
(6 \mathrm{~mm})\end{array}$ & $\begin{array}{c}\text { OSB } \\
(10 \mathrm{~mm})\end{array}$ & $\begin{array}{c}\text { OSB } \\
(15 \mathrm{~mm})\end{array}$ & $\begin{array}{c}\text { OSB } \\
(18 \mathrm{~mm})\end{array}$ & $\begin{array}{c}\text { WPB } \\
(24 \mathrm{~mm})\end{array}$ \\
\hline 35 & 78.5 & 75.8 & 74.7 & 72.1 & - & 75.25 & 84,18 & 76.37 & 73.93 & 72.47 & - \\
\hline 40 & 29.6 & 28.2 & 27.8 & 27.2 & 41.2 & $\begin{array}{l}28.85(\mathrm{OSB}) \\
43.17 \text { (WPB) }\end{array}$ & 30.13 & 29.42 & 28.54 & 28.00 & 43.20 \\
\hline 45 & 27.5 & 22.3 & 23.1 & 24.1 & 22.2 & 23.17 & 24.67 & 23.89 & 23.01 & 22.47 & 21.41 \\
\hline 50 & 18.4 & 18.8 & 17.9 & 16.9 & 13.9 & 17.48 & 19.07 & 18.36 & 17.48 & 16.94 & 15.88 \\
\hline
\end{tabular}

results suggest, TTI values can be forecasted promptly and accurately enough in accordance with the Eqns (1) and (3). However, slightly more accurate results can be obtained when forecasting uses the Eqns (2) and (4).

\section{Conclusions}

The TTI of OSB and WPB when exposed to a heat flow with powers exceeding $35 \mathrm{~kW} / \mathrm{m}^{2}$ almost does not change compared to similar non-impregnated samples.

When exposed to a heat flow with power of $35 \mathrm{~kW} / \mathrm{m}^{2}$, some WPB samples did not ignite but rather charred. Therefore, it is recommended to use WPB impregnated with fire retardant.

The $\mathrm{HRR}_{\max }$ (HRR) values (i.e. the highest amount of heat released during combustion) for all samples was reached after approximately 160 seconds after ignition. It is a very short period of time, which would pose danger to human life in case of real fire.

The best fire resistance properties were demonstrated by WPB impregnated with fire retardant solution, the fire growth rate (FIGRA) and the entire amount of heat released of which were almost 2.5 times lower than that of a non-impregnated board.

Fire retardant solution not only worsens the combustion properties of wood and increases the flammability class but also decreases the amount of $\mathrm{CO}_{2}$ emission.

Prompt forecasting of the TTI (s) can be made according to the heat flow $\left(Q, \mathrm{~kW} / \mathrm{m}^{2}\right)$ to which the sample is exposed and more accurate forecasting is possible once its thickness $(D, \mathrm{~mm})$ is also taken into consideration. The aforementioned indicators are sufficient for making rather accurate forecasting and deciding on the combustibility of OSB and WPB.

\section{References}

Babrauskas, V. 2005. Charring rate of wood as a tool for fire investigations, Fire Safety Journal 40(6): 528-554. http://dx.doi.org/10.1016/j.firesaf.2005.05.006

Babrauskas, V.; Peacock, R. D. 1992. Heat release rate: the single most important variable in fire hazard, Fire Safety Journal 18(2): 55-72. http://dx.doi.org/10.1016/0379-7112(92)90019-9 
Bednarek, Z.; Griškevičius, M.; Šaučiuvėnas, G. 2009. Tensile, compressive and flexural strength reduction of timber in fire, Statybines konstrukcijos ir technologijos 3(3): 148-156. http://dx.doi.org/10.3846/skt.2009.18

Bednarek, Z.; Kaliszuk-Wietecka, A. 2007. Analysis of the fire-protection impregnation influence on wood strength, Journal of Civil Engineering and Management 13(2): 79-85.

http://dx.doi.org/10.1080/13923730.2007.9636423

Borovikov, V. P. 1998. Populiarnoe vvedenie v programmu STATISTIKA [Popular introduction to the program STATISTIKA]. Moskva: Kompiuter Press. 267 s. (in Russian).

Bridžiuvienè, D.; Lugauskas, A. 2003. Evaluation of the efficiency of some on offers wood preservatives, Materials Science (Medžiagotyra) 9(4): 363-367.

Chou, C. S.; Lin, S. H.; Wang, C. I. 2009. Preparation and characterization of the intumescent fire retardant coating with a new flame retardant, Advanced Powder Technology 20(2): 169-176.

http://dx.doi.org/10.1016/j.apt.2008.07.002

Chow, C. L.; Chow, W. K. 2009. Fire safety aspects of refuge floors in supertall buildings with computational fluid dynamics, Journal of Civil Engineering and Management 15(3): 225-236.

http://dx.doi.org/10.3846/1392-3730.2009.15.225-236

Draizdeil, D.1998. An introduction to fire dynamics. 2nd ed. West Sussex, England: Wiley. 447 p.

Filipczak, R.; Crowley, S.; Lyon, R. E. 2005. Heat release rate measurements of thin samples in the OSU apparatus and the cone calorimeter, Fire Safety Journal 40(7): 628-645.

http://dx.doi.org/10.1016/j.firesaf.2005.05.009

Frangi, A.; Fontana, M.; Hugi, E.; Jübstl, R. 2009. Experimental analysis of cross laminated timber panels in fire, Fire Safety Journal 44(8): 1078-1087. http://dx.doi.org/10.1016/j.firesaf.2009.07.007

Hakkarainen, T. 2002. Post-flashover fires in light and heavy timber construction compartments, Journal of Fire Sciences 20(2): 133-175. http://dx.doi.org/10.1177/0734904102020002074

Kleinbaum, D. G.; Kupper, L. L.; Muller, K. E.; Niram, A. 1998. Statistical analysis. Brooks/Cole Publishing Company. 798 p.

LST EN 13823:2010. Statybiniu gaminiu reakcijos $i$ ugni bandymai. Statybiniai gaminiai, išskyrus grindu dangas, kuriuos veikia vieno degančio objekto šiluma [Reaction to fire tests for building products - building products excluding floorings exposed to the thermal attack by a single burning item]. Vilnius: Lithuanian Standards Board, 2010. 92 p.

LST EN 13501-1:2007+A1:2010. Statybos gaminiu ir pastato elementu klasifikavimas pagal atsparuma ugniai. 1 dalis. Klasifikavimas pagal atsako $i$ ugni bandymu duomenis [Fire classification of construction products and building elements - part 1: Classification using data from reaction to fire tests]. Vilnius: Lithuanian Standards Board, 2010. 53 p.

LST ISO 5657:1999. Reagavimo ì ugni bandymai. Statybiniu gaminiu užsidegimas veikiant juos šilumine spinduliuote [Reaction to fire test. Ignitability of building products using a radiant heat source]. Vilnius: Lithuanian Standards Board, 1999. 42 p.

Mačiulaitis, R.; Praniauskas, V. 2010. Fire tests on wood products subjected to different heat fluxes, Journal of Civil Engineering and Management 16(4): 484-490. http://dx.doi.org/10.3846/jcem.2010.54

Morkevičius, A.; Papreckis, B. 2004. Mediena ir jos gaminiai [Wood and wood products]. Vilnius: Senoja. 239 p. (in Lithuanian).

Mouritz, A. P.; Mathys, Z.; Gibson, A. G. 2006. Heat release of polymer composites in fire, Composites, Part A: Applied Science and Manufacturing 37(7): 1040-1054. http://dx.doi.org/10.1016/j.compositesa.2005.01.030

Nyderis, A.; Mačiulaitis, R. 1999. Putu polisterenu apšiltintu fasado fragmentu gaisriniai bandymai [Fire testing of the building facade insulated with foam polystyrene], Staty $b a$ [Civil Engineering] 5(5): 340-346 (in Lithuanian). http://dx.doi.org/10.1080/13921525.1999.10531486

Pereyra, A. M.; Giudice, C. A. 2009. Flame-retardant impregnants for woods based on alkaline silicates, Fire Safety Journal 44(4): 497-503. http://dx.doi.org/10.1016/j.firesaf.2008.10.004

Półka, M. 2008. The influence of flame retardant additives on fire properties of epoxy materials, Journal of Civil Engineering and Management 14(1): 45-48. http://dx.doi.org/10.3846/1392-3730.2008.14.45-48

Praniauskas, V.; Mačiulaitis, R.; Lipinskas, D. 2010. Research of various fire-retardant treated wood species, in Proceedings of the 10th International Conference "Modern buildings materials, structures and techniques”, 19-21 May, 2010, Vilnius, Lithuania. Selected papers, vol. 2, 1286-1291.

Richardson, L. R.; Batista, M. 2001. Fire resistance of timber decking for heavy timber construction, Fire and Materials 25(1): 21-29.

http://dx.doi.org/10.1002/1099-1018(200101/02) 25:1<21::AID-FAM754>3.0.CO;2-E

Rudskienè, V.; Kulvietienè, R. 1995. Kompiuterine duomenu analize [Computerized analysis of the data]. Vilnius: Technika. 47 p. (in Lithuanian).

Šaučiuvènas, G.; Griškevičius, M. 2009. Medinių centriškai gniuždomų elementų elgsena ugnyje [The behaviour of axial compression timber elements at fire], Statybines konstrukcijos ir technologijos 1(1): 50-57. http://dx.doi.org/10.3846/skt.2009.06

Wang, Z.; Han, E.; Ke, W. 2007. Influence of expandable graphite on fire resistance and water resistance of flameretardant coatings, Corrosion Science 49(5): 2237-2253. http://dx.doi.org/10.1016/j.corsci.2006.10.024

White, R. H. 2000. Charring rate of composite timber products, in Proceedings of Wood \& Fire Safety 2000, Technical University of Zvolen, Slovak Republic, 353-363.

Władyka-Przybylak, M. 1997. Badanie skutecznosci ogniochronnej powłok peczniejacych do drewna $w$ zależności od zastosowanych mody-fikatorów [Study the effectiveness of fire-retardant coatings for wood swell, depending on the used modifiers]. PhD thesis. Institute of Natural Fibres, Poznań, Poland. 80 p. (in Polish).

Žukas, A.; Mačiulaitis, R.; Šukys, R. 2007. Statybos produktu panaudojimo gaisrine sauga [Fire safety of use of construction products]: Mokomoji knyga. Vilnius: Technika. 112 p. (in Lithuanian). 
Romualdas MAČIULAITIS. Prof. Doctor Habil of Technological Sciences. He works at Department of Building Materials of Vilnius Gediminas Technical University (VGTU). Research interests: development of building materials and analysis of their characteristics.

Vladas PRANIAUSKAS. Doctor of Technological Sciences. He works at the Fire Research Centre of the Fire and Rescue Department under the Ministry of the Interior (PAGD prie VRM GTC). Research interests: fire resistance and flammability research of building materials.

Grigory YAKOVLEV. Prof. Doctor Habil of Building Materials. He works as head of Department of Building Materials in Kalashnikov Izhevsk State Technical University (Kalashnikov IzhGTU). Research interests: nanotechnology for green and sustainable construction. 